\title{
Association of adiponectin with cognitive function precedes overt diabetes in the Brazilian Longitudinal Study of Adult Health: ELSA
}

\author{
Adriana Cezaretto ${ }^{1}$, Claudia Kimie Suemoto ${ }^{2}$, Isabela Bensenor ${ }^{3}$, Paulo A. Lotufo ${ }^{3}$, Bianca de Almeida-Pititto ${ }^{1}$ \\ and Sandra R. G. Ferreira ${ }^{1 *}$ on behalf of the ELSA Research Group
}

\begin{abstract}
Background: Adiponectin is an insulin-sensitizer adipocytokine endowed with neuroprotective actions. Whether adiponectin regulates neuronal functioning toward delaying cognitive decline independently of the glucose metabolism disturbance has been poorly explored. This study evaluated if the performance in cognitive tests was associated with adiponectin levels prior the development of type 2 diabetes in middle-aged individuals.

Methods: A sample of 938 non-diabetic participants of ELSA had their cognitive function assessed by the CERAD delayed word recall test, the verbal fluency test and the trail making test. Stepwise multiple linear regression using forward selection had the response to cognitive tests as the dependent variable and adiponectin as the independent variable of main interest, adjusted for glucose tolerance status and confounders.

Results: Mean age was $45.7 \pm 4.9$ years, $54.5 \%$ were women, $43.0 \%$ had high education level, $59.3 \%$ weight excess and $70.0 \%$ prediabetes. In crude model, only the delayed recall memory was associated with adiponectin levels. In an initial regression model, delayed recall memory remained independently associated with adiponectin levels and prediabetes. After complete adjustments, adiponectin but not prediabetes maintained independently associated with delayed recall memory $(\beta 0.067 ; 95 \% \mathrm{Cl} 0.006-0.234 ; \mathrm{p}=0.040)$. On the other hand, learning memory showed to be associated with prediabetes $(\beta 0.7195 \% \mathrm{Cl} 0.17 ; 1.24 ; \mathrm{p}=0.009)$ but not with adiponectin.

Conclusions: The association of memory with adiponectin in middle-aged individuals, prior overt diabetes, suggests that this adipocytokine could anticipate cognitive impairment $\rho$ detection, when preventive strategies could be more effectively implemented. The usefulness of adiponectin to identify increased risk for cognitive dysfunction before advanced age needs to be prospectively investigated in ELSA cohort.
\end{abstract}

Keywords: Adiponectin, Prediabetes, Cognitive function, Dementia, Prevention

\section{Background}

The importance of adiponectin discovery was initially based on its role on the glucose metabolism and obesityrelated diseases $[1,2]$. This adipocytokine exerts insulin-sensitizing effects via specific receptors (AdipoRs) expressed in several tissues [3]. Benefits of adiponectin on immune system and neuronal function were further

\footnotetext{
*Correspondence: sandrafv@usp.br

${ }^{1}$ Department of Epidemiology, School of Public Health, University of Sao Paulo, São Paulo, Brazil

Full list of author information is available at the end of the article
}

reported [4]. In the brain, AdipoRs were found in hippocampus, cortex and hypothalamus, and adiponectin administration to animals induced neurogenesis [5]. Its anti-inflammatory and neuroprotective actions motivated investigations on the pathophysiology of neurodegenerative disorders such as dementias [6, 7].

Prevalence of dementias is high in elderly living in developing an developed countries; Alzheimer's disease is the most common cause of dementia in older adults and the sixth leading cause of death in the United States $[8,9]$.

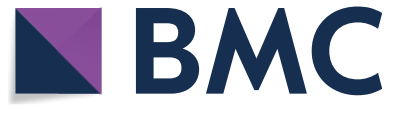

(c) The Author(s) 2018. This article is distributed under the terms of the Creative Commons Attribution 4.0 International License (http://creativecommons.org/licenses/by/4.0/), which permits unrestricted use, distribution, and reproduction in any medium, provided you give appropriate credit to the original author(s) and the source, provide a link to the Creative Commons license, and indicate if changes were made. The Creative Commons Public Domain Dedication waiver (http://creativecommons.org/ publicdomain/zero/1.0/) applies to the data made available in this article, unless otherwise stated. 
A metanalysis revealed that type 2 diabetes mellitus (DM) was associated with 39\% increased risk of Alzheimer's disease, and 138\% increased risk of vascular dementia compared to non diabetic individuals [10]. The combination of these diseases potentiates morbidity and accelerates mortality mainly from cardiovascular events $[10,11]$. Several lines of evidence have shown that neuroinflammation and insulin resistance play an important role in the pathogenesis of dementia [12], explaining its association with metabolic disorders such as DM. Since hippocampal cognitive functioning depends on the insulin-stimulated glucose uptake, states of insulin resistance might contribute to impair memory performance [13, 14]. Extracellular amiloid- $\beta$ accumulation, synaptic loss and neuronal death are some pathophysiological features attributed to insulin resistance $[12,15]$. Even in prediabetic phase, there is some evidence of a reduced cognitive function [16]. Since insulin has a central role in learning and memory, and adiponectin an insulin-sensitizing effect, the latter represents a potential therapeutic target against dementia.

Considering that neuropathological lesions start 20 years before the onset of clinically symptoms [17], early detection of cognitive decline might be useful to prevent dementia through lifestyle changes and pharmacological interventions [18]. Whether adiponectin exerts protective effect on glucose metabolism and neuronal functioning delaying the onset of metabolic and neurodegenerative diseases in middle-aged individuals remains poorly investigated.

The Longitudinal Study of Adult Health (ELSA-Brasil) is multicenter study designed to investigate the incidence of DM and cardiovascular disease, and their biological, behavioral, environmental, occupational, psychological and social risk factors. This also represents a unique opportunity to investigate association of an early marker of dementia risk. We hypothesized that adiponectin concentration could be associated with improved cognitive performance before advanced age, independently of the glucose metabolism status. We aimed to evaluate if the performance in cognitive tests was associated with adiponectin levels, in middle-aged non-diabetic participants at the baseline of the ELSA-Brasil.

\section{Methods}

\section{Participants}

Objectives, study population, and methods of the ELSABrasil were previously reported $[19,20]$. Briefly, 15,105 ( $54 \%$ women) active or retired employees of six Brazilian universities, aged $35-74$ years, were eligible for baseline examinations of the cohort study. They had an initial interview and then scheduled for clinical examination and laboratory tests in research centers. This study was approved by the institutional ethics committee of the University of Sao Paulo, and written consent was obtained from all participants.

The present cross-sectional analysis was performed with baseline data of a sample of 1000 individuals from the 5061 participants of the research center in São Paulo. Inclusion criteria were 35-54 years of age; exclusion criteria were clinical history of DM and/or cardiovascular disease; use of medications which could interfere in the cognitive function (neuroleptics, antiparkinsonian and anticonvulsant agents); C-reactive protein concentration $>10 \mathrm{mg} / \mathrm{L}$. Sixty participants did not meet eligibility criteria, and two individuals were excluded from analyses due to insufficient aliquot volume for biomarkers determinations [21]. Participants were interviewed using standardized questionnaires to obtain sociodemographic and lifestyle data. Afterwards, they were scheduled for clinical examination and laboratory procedures.

\section{Cognitive function assessment}

The neuropsychological tests used for the assessment of cognitive function were: the Consortium to Establish a Registry for Alzheimer's Disease (CERAD) delayed word recall test [22], fluence test and trail making test, version B. A Brazilian version of CERAD including a ten-word list was used to evaluate verbal learning memory, delayed recall memory, and recognition of verbal memory [23, 24]. Participants were asked to read 10 words and, after $5 \mathrm{~min}$, they had $60 \mathrm{~s}$ to record these words. The score was equal to the number of recalled words. The semantic (animal category) and phonemic (letter F) verbal fluency tests were used to evaluate the language domain, and the score corresponded to the total number of generated words by the participant [24]. The higher the scores the better cognitive function in those domains. The trail making test was used to evaluate executive function, as it is related to attention, concentration, and psychomotor speed. The score corresponded to the time (in seconds) taken to complete the test. The longer the time taken to complete, the worse the participant's performance.

\section{Other measures}

The presence of depression was assessed by the Clinical Interview Schedule-Revised [25] and diagnosed according to ICD-10 [26]. Physical activity level was assessed using the International Physical Activity Questionnaire, and took account of the sum of the activities related to leisure and commuting $[27,28]$. Body weight and height were measured using calibrated electronic scales and a fixed rigid stadiometer. Body mass index (BMI) was calculated as weight (kilograms) divided by squared height 
(meters). Abdominal circumference was measured with an inextensible tape. Blood pressure was taken three times after a 5-min rest in the sitting position; the mean of the second and third measurements was used [29]. Hypertension was defined as systolic or diastolic blood pressure higher than $140 / 90 \mathrm{mmHg}$ or antihypertensive treatment.

Participants underwent a 2-h 75-gram oral glucose tolerance test. Prediabetes was defined according to American Diabetes Association criteria [30]. Insulin resistance was assessed by the homeostasis model assessmentinsulin resistance (HOMA-IR) index. Dyslipidemia was characterized by LDL-cholesterol $\geq 130 \mathrm{mg} / \mathrm{dL}$ and/or lipid-lowering agents use. Hypothyroidism was defined by TSH levels $>4.0 \mathrm{IU} / \mathrm{L}$ and free $\mathrm{T} 4<0.8 \mu \mathrm{g} / \mathrm{dL}$, while hyperthyroidism by THS levels $<0.4 \mathrm{IU} / \mathrm{L}$ and free $\mathrm{T} 4 \geq 1.9 \mu \mathrm{g} / \mathrm{dL}$.

\section{Analytical procedures}

Plasma glucose was determined by the hexokinase method, and HDL-cholesterol by homogeneous colorimetric, without precipitation (ADVIA Chemistry; Siemens, Deerfield, Illinois, USA). LDL-cholesterol was calculated using the Friedewald equation. When triglyceride concentration was greater than $400 \mathrm{mg} / \mathrm{dL}$, the LDL-cholesterol level was directly measured [31]. Immunochemistry was used to measure high-sensitivity C-reactive protein (Dade Behring, Siemens, Marburg, Germany), and enzyme-linked immunoenzymatic assay for insulin (Siemens, Tarrytown, USA) and adiponectin determinations (Enzo Life Sciences, Farmingdale, NY, USA). Intra-assay and inter-assay coefficients of variation ranged from 1.8 to $7.2 \%$, and from 0.9 to $14.4 \%$, respectively [21].

\section{Statistical analysis}

Descriptive data were shown as frequencies of categorical variables, or as mean and standard deviation (SD) for continuous variables. Student $t$ test or Chi square test was used to compare variables between normotolerant with prediabetic participants. Continuous variables with skewed distribution were log-transformed (adiponectin, HOMA-IR and C-reactive protein) or Mann-Whitney test was used. Simple linear regression was used to test association of cognitive function domains with clinical variables and adiponectin. Cognition domains (learning memory, delayed recall memory, recognition memory, trail test, and fluency tests) were the dependent variables, adiponectin the independent variable of main interest in inward multiple linear regression analyses. Due to the recognized association of glucose metabolism disturbance with cognition performance, association of adiponectin with cognitive function was initially tested in the presence of prediabetes. Afterwards, models were adjusted for demographics, anthropometric data, lifestyle variables (physical activity, smoking and alcohol use), HOMA-IR, C-reactive protein, hypertension, dyslipidemia, depression and thyroid dysfunction. Additionally, an interaction term (adiponectin*HOMA-IR) was tested. SPSS software, version 19.0 for Windows (SPSS Inc., Chicago, Illinois, USA) was used. A p-value of 0.05 was considered significant.

\section{Results}

The mean age of 938 participants was 45.7 years (SD 4.9); $54.5 \%$ were women and nearly $70 \%$ had prediabetes. A higher frequency of women had university level compared to men $(52.3 \%$ versus $30.9 \%$; $\mathrm{p}<0.001)$. Moreover, women were less likely to consume alcohol $(67.9 \%$ versus $76.3 \%, \mathrm{p}<0.001)$ and to be current smokers $(14.7 \%$ versus $22.5 \%, \mathrm{p}<0.001)$ than men. Lower abdominal circumference $\left(83.3 \pm 10.7\right.$ versus $\left.91.3 \pm 10.7 \mathrm{~kg} / \mathrm{m}^{2}, \mathrm{p}=0.031\right)$, systolic and blood pressure levels (112 \pm 13 versus $122 \pm 14$ and $72 \pm 10$ versus $78 \pm 10 \mathrm{mmHg}, \mathrm{p}<0.001)$, fasting plasma glucose $(100.0 \pm 7.3$ versus $105.0 \pm 8.7 \mathrm{mg} /$ $\mathrm{dL}, \mathrm{p}<0.001)$, and higher adiponectin concentration $(13.8 \pm 18.6$ versus $12.3 \pm 15.1 \mu \mathrm{g} / \mathrm{mL}, \mathrm{p}<0.001)$ and better performance in domains of cognitive function than men (data not shown in tables).

Stratifying by the glucose tolerance status (Table 1), more men than women had prediabetes. Prediabetic individuals were older, had higher mean values of anthropometric data, blood pressure and biochemical variables compared to normotolerant ones. Furthermore, prediabetic individuals had lower adiponectin concentration and poorer scores of learning and delayed recall memories.

Associations between domains of cognitive function and clinical variables are depicted in Table 2. In general, the domains of learning and delayed recall memories were the most significantly associated with clinical variables. Age, BMI, blood pressure levels, plasma glucose, and triglycerides were inversely associated with learning and delayed recall memories and directly with trail test scores. Some significant associations of insulin resistance index and C-reactive protein with selected domains of cognitive were also detected.

Simple and multiple linear regression models for the associations of adiponectin with the domains of cognitive function are shown in Table 3 . In crude models, adiponectin concentration was associated with memory, reaching statistical significance only for the delayed recall memory. In additional analyses, associations between adiponectin with BMI $(\beta-0.042, p=0.200)$, C-reactive protein $(\beta-0.069, p=0.037)$, and with HOMA-IR $(\beta$ 
Table 1 Demographic, lifestyle, clinical, and cognitive domains data of participants stratifyed according to glucose tolerance status

\begin{tabular}{|c|c|c|c|}
\hline & $\begin{array}{l}\text { Normoglycemia } \\
N=278\end{array}$ & $\begin{array}{l}\text { Prediabetes } \\
N=660\end{array}$ & p-value \\
\hline \multicolumn{4}{|l|}{ Clinical variables } \\
\hline Women (\%) & 71.9 & 47.1 & $<0.001$ \\
\hline Caucasian (\%) & 62.6 & 59.2 & 0.344 \\
\hline Current smoker (\%) & $18.0(50)$ & $18.3(121)$ & 0.071 \\
\hline Current alcohol user (\%) & $70.1(195)$ & $72.4(478)$ & 0.227 \\
\hline Physical activity (days/week) & $1.30(0.62)$ & $1.31(0.63)$ & 0.846 \\
\hline Age (years) & $44.9(4.9)$ & $46.1(4.9)$ & $<0.001$ \\
\hline Body mass index $\left(\mathrm{kg} / \mathrm{m}^{2}\right)$ & $25.4(3.7)$ & $26.7(4.1)$ & $<0.001$ \\
\hline Abdominal circumference $(\mathrm{cm})$ & $82.5(9.8)$ & $88.4(11.3)$ & $<0.001$ \\
\hline Systolic blood pressure (mmHg) & $112(13)$ & $119(14)$ & $<0.001$ \\
\hline Diastolic blood pressure $(\mathrm{mmHg})$ & $71(10)$ & $76(10)$ & $<0.001$ \\
\hline Plasma glucose (mg/dL) & $94.4(3.8)$ & $105.7(6.8)$ & $<0.001$ \\
\hline Triglycerides (mg/dL) & $101.3(50.5)$ & $138.6(83.3)$ & $<0.001$ \\
\hline LDL-cholesterol (mg/dL) & $122.7(28.7)$ & $131.5(33.5)$ & $<0.001$ \\
\hline HDL-cholesterol (mg/dL) & $59.3(13.1)$ & $53.7(12.9)$ & $<0.001$ \\
\hline $\mathrm{HOMA}-\mathrm{R}^{\mathrm{a}}$ & $1.32(1.01)$ & $2.04(1.58)$ & $<0.001$ \\
\hline C-reactive protein ${ }^{\mathrm{a}}(\mathrm{mg} / \mathrm{L})$ & $2.03(2.13)$ & $2.06(2.01)$ & 0.308 \\
\hline Adiponectin $(\mu \mathrm{g} / \mathrm{mL})$ & $14.3(23.5)$ & $12.6(13.5)$ & 0.127 \\
\hline \multicolumn{4}{|l|}{ Cognitive function } \\
\hline Learning memory & $21.0(3.6)$ & $20.4(3.9)$ & 0.031 \\
\hline Delayed recall memory & $7.1(1.9)$ & $6.7(1.9)$ & 0.015 \\
\hline Recognition memory & $9.7(0.7)$ & $9.5(0.9)$ & 0.095 \\
\hline Semantic verbal fluency test & $18.3(4.7)$ & $18.4(4.8)$ & 0.663 \\
\hline Phonemic verbal fluency test & $12.3(4.3)$ & $12.4(4.5)$ & 0.727 \\
\hline Trail test & $100.5(65.9)$ & $109.7(70.3)$ & 0.055 \\
\hline
\end{tabular}

Data are presented by frequencies or means and standard deviations

${ }^{a}$ Mann-Whitney test used

Table 2 Coefficients of simple linear regression between domains of cognitive function and clinical and biochemical data

\begin{tabular}{|c|c|c|c|c|c|c|c|c|c|c|c|c|}
\hline & \multicolumn{2}{|c|}{ Learning memory } & \multicolumn{2}{|c|}{$\begin{array}{l}\text { Delayed recall } \\
\text { memory }\end{array}$} & \multicolumn{2}{|c|}{$\begin{array}{l}\text { Recognition } \\
\text { memory }\end{array}$} & \multicolumn{2}{|c|}{$\begin{array}{l}\text { Semantic verbal } \\
\text { fluency test }\end{array}$} & \multicolumn{2}{|c|}{$\begin{array}{l}\text { Phonemic verbal } \\
\text { fluency test }\end{array}$} & \multicolumn{2}{|c|}{ Trail test } \\
\hline & $\beta$ & $p$-value & $\mathbf{B}$ & p-value & B & p-value & $\mathbf{B}$ & p-value & $\beta$ & $p$-value & B & p-value \\
\hline Age & -0.105 & 0.001 & -0.142 & $<0.001$ & 0.004 & 0.896 & -0.081 & 0.013 & -0.041 & 0.208 & 0.259 & $<0.001$ \\
\hline Body mass index & -0.105 & 0.001 & -0.089 & 0.006 & -0.038 & 0.253 & -0.062 & 0.057 & -0.046 & 0.162 & 0.092 & 0.005 \\
\hline Systolic BP & -0.124 & $<0.001$ & -0.154 & $<0.001$ & -0.082 & 0.012 & -0.111 & 0.001 & -0.119 & $<0.001$ & 0.117 & $<0.001$ \\
\hline Diastolic BP & -0.082 & 0.013 & -0.119 & $<0.001$ & -0.073 & 0.026 & -0.109 & 0.001 & -0.125 & $<0.001$ & 0.101 & 0.002 \\
\hline Plasma glucose & -0.108 & $<0.001$ & -0.127 & $<0.001$ & -0.035 & 0.287 & -0.016 & 0.634 & -0.058 & 0.079 & 0.095 & 0.004 \\
\hline Triglycerides & -0.138 & $<0.001$ & -0.173 & $<0.001$ & -0.068 & 0.040 & -0.065 & 0.050 & -0.044 & 0.183 & 0.075 & 0.024 \\
\hline HDL-cholesterol & 0.135 & $<0.001$ & 0.187 & $<0.001$ & 0.070 & 0.034 & 0.092 & 0.005 & 0.093 & 0.005 & -0.093 & 0.005 \\
\hline LDL-cholesterol & 0.037 & 0.261 & 0.030 & 0.359 & -0.002 & 0.947 & 0.025 & 0.450 & 0.023 & 0.484 & -0.039 & 0.242 \\
\hline HOMA-IR & -0.087 & 0.008 & -0.089 & 0.007 & -0.012 & 0.722 & -0.015 & 0.653 & -0.043 & 0.192 & 0.004 & 0.911 \\
\hline CRPa & -0.032 & 0.329 & -0.056 & 0.085 & -0.019 & 0.554 & -0.105 & 0.001 & -0.046 & 0.161 & 0.084 & 0.011 \\
\hline
\end{tabular}

$B P$ blood pressure, $H D L$ high-density lipoprotein, $L D L$ low-density lipoprotein, HOMA-IR homeostasis model assessment-insulin resistance, CRP C-reactive protein

${ }^{\text {a }}$ Log-transformed variables for analysis. Simple linear regression used 
$-0.092, \mathrm{p}=0.005)$ were detected. In model 1 of multiple linear regression, adiponectin levels showed to be associated with delayed recall memory (Table 3), while prediabetes with learning memory $(\beta-0.080 ; p=0.015)$ and delayed recall memory $(\beta-0.083 ; p=0.012)$. After adjustments (model 2), adiponectin but not prediabetes maintained independently associated with delayed recall memory. In the same model, significant associations of delayed recall memory with the female sex $[\beta 0.243$ $(95 \%$ CI $0.675 ; 1.212)]$, age $[\beta-0.110(95 \%$ CI -0.071 ; $-0.018)]$, and education level $[\beta 0.205$ (95\% CI 0.535 ; 1.063)] were also detected. The inclusion of the interaction variable adiponectin"HOMA-IR did not change the association between adiponectin levels with improved delayed recall memory.

\section{Discussion}

Our finding of association of memory domains with adiponectin levels at midlife suggests a role of this adipocytokine in early identification of high-risk individuals to cognition impairment, and supports previous assumption that it could represent a promising therapeutic target to protect against dementia. Independently of the recognized adverse effects of aging and abnormalities of glucose metabolism in the cognitive function, adjustments for both did not abolish the association of adiponectin with the delayed recall memory. Considering that insulin resistance is an underlying mechanism of type $2 \mathrm{DM}$ and cognition impairment, and that adiponectin improves insulin signaling and glucose uptake, we suggest that the determination of this adipocytokine level could help to detect at-risk individuals before advanced age, in presymptomatic stages of the diseases.

The sample studied had some particularities, such as having included middle-aged highly-educated individuals and predominance of women. A neuroprotective role of schooling, able to elevate cognitive reserve, has been reported [32,33], which could have contributed to optimal cognitive performance seen in participants of the present study. Our findings indicated better cognition scores in women compared to men. This finding is in agreement with studies investigating age- and sex-related cognitive performances, in which healthy men showed greater cognitive decline than women $[34,35]$, but differs from others [36]. Better scores observed among women from our study could be attributed in part to a better lifestyle than men and to their high education level. Actually, low education had been already associated with a fivefold increase in prevalence of cognition decline in a study conducted in Latin America [37]. We speculate that the ELSA highly-educated participants of both sexes might have a great cognitive reserve [32,33], that could be protecting them against cognition impairment. In women, their good performance could be also explained by high proportion of premenopausal ones, in whom estrogen level could be preserving memory [38].

Based on a recognized tool to dementia assessment (CERAD), participants with mild disturbance of glucose tolerance (prediabetes) already showed a worse cognitive performance (namely learning and delayed recall memory) when compared to normotolerant ones. Association of dysglicemia and cognition dysfunction was previously described with predominance in male sex at high cardiovascular risk [39-41]. Although we had observed higher proportion of men with prediabetes in our study, sex-related difference cannot be assured since a convenience sample was studied. As expected, prediabetic participants were older and had worse insulin sensitivity and metabolic profile, which are known to impair cognitive function [12].

We verified that memory domains, but not fluency and trail tests, were worse in prediabetic than in normal tolerant individuals. Memory, which is mainly controlled by hippocampal neurons, has been shown as the first

Table 3 Coefficients (95\% confidence interval) of the association between domains of cognitive function and adiponectin levels using linear regression

\begin{tabular}{|c|c|c|c|c|c|c|}
\hline & \multirow[t]{2}{*}{ Crude model } & \multirow[t]{2}{*}{ p-value } & \multicolumn{4}{|c|}{ Multiple linear regression } \\
\hline & & & Model 1 & $p$-value & Model 2 & p-value \\
\hline Learning memory & $0.062(-0.012 ; 0.449)$ & 0.063 & $0.063(-0.009 ; 0.451)$ & 0.059 & $0.045(-0.068 ; 0.386)$ & 0.170 \\
\hline Delayed recall memory & $0.084(0.033 ; 0.266)$ & 0.012 & $0.085(0.035 ; 0.267)$ & 0.011 & $0.067(0.006,0.234)$ & 0.040 \\
\hline Recognition memory & $0.035(-0.025 ; 0.082)$ & 0.298 & - & - & - & - \\
\hline Semantic verbal fluency test & $-0.011(-0.337 ; 0.242)$ & 0.746 & - & - & - & - \\
\hline Phonemic verbal fluency test & $-0.006(-0.290 ; 0.238)$ & 0.849 & - & - & - & - \\
\hline Trail making test & $-0.015(-5.153 ; 3.271)$ & 0.661 & - & - & - & - \\
\hline
\end{tabular}

Model 1: adjusted for the presence of prediabetes

Model 2: adjusted for sex $(p<0.001)$, age $(p<0.001)$, education $(p<0.001)$, physical activity, alcohol use, smoking, depression, thyroid dysfunction, BMI, HOMA-IR, hypertension, dyslipidemia, C-reactive protein 
domain affected during the cognitive decline process [42]. Since glucose uptake by the hippocampus depends on insulin, several lines of investigation have implicated insulin resistance in the development of dementia [10, 12, $15]$ that manifests late in life. Our sample was composed of middle-aged individuals-in whom clinically relevant cognitive impairment is uncommon-but with a high frequency of prediabetes. Therefore, findings of our study suggest that the presence of mild disturbances of glucose metabolism, prior to overt DM, may deserve screening for cognition function independently of the age. Considering that an early detection of cognitive impairment in midlife could improve efficacy of preventive measures, risk assessment becomes even more important in prediabetes due to its potential to accelerate rate of cognitive decline $[43,44]$. Few studies have been conducted in prediabetic individuals and have suggested better outcomes $[39,43,45]$.

The most important finding of our study is related to the adiponectin, involved in the mechanism of neuronal injury, potentially able to improve risk detection of neurodegenerative diseases. Although still within reference ranges [46], higher adiponectin levels were associated with better delayed recall memory, independently of demographic variables and glucose metabolism disturbance. Since cerebral insulin resistance leads to increased amyloid $\beta$ accumulation which causes synaptic damage [15], the insulin-sensitizing effect adiponectin seems desirable to preserve memory $[47,48]$. Additionally, our final model of linear regression was consistent with the importance of aging for memory deterioration and education for memory maintenance [49]. Even controlling for these variables, adiponectin values, but not prediabetes, maintained significant association with memory. We interpreted that such association could be indicating an adiponectin-induced neuroprotective effect. It was demonstrated that stimulation of AdipoRs induces benefits not only on insulin signaling but also on inflammation and oxidative stress $[50,51]$. In animals, when administered in the brain, adiponectin was able to suppress cytokines production by microglia [52]. Also, adequate adiponectin levels induced inhibition of TNF- $\alpha$ inflammatory effects and were able to prevent circulating inflammatory cytokines to cross the blood-brain barrier [53]. Therefore, its insulin-sensitizing, anti-inflammatory and antioxidant properties should be protecting against amyloid $\beta$ accumulation and neuronal damage [54].

Taking adiponectin beneficial effects into consideration, novel therapies for Alzheimer's disease, based on AdipoR agonists, have been proposed. However, such proposition contrasts with some studies conducted in elderly (age $\geq 70$ years) that have described increased adiponectin levels in Alzheimer's disease [55, 56]. The "adiponectin paradox" has been reported in association with a metabolically healthy obese phenotype. These findings reflect the complexity of therapy strategies addressed to adiponectin receptor signaling in agingrelated chronic diseases [57].

We considered that the weak but significant association detected between memory and adiponectin in middleaged individuals suggests that a lower adiponectin level could be indicative of an increased risk for cognitive impairment, when interventions might be more effective. Considering the growing proportion of older people for the next decades worldwide, earlier identification of individuals at higher risk is desirable in an attempt to delay dementia and preserve quality of life.

Our study has the limitation of having investigated a specific population at-risk for type $2 \mathrm{DM}$, that impedes extrapolation to the general population. However, it had the strength of having studied a large sample of middleaged individuals with preserved neurocognitive function. Our results contribute to the knowledge about prevalent insulin resistance-linked diseases, in which adiponectin seems to play an important protective role at least during midlife. However, our cross-sectional analysis precludes investigating causality. The ELSA-Brasil cohort is promising to examine prospectively the ability of serum adiponectin to predict cognitive impairment in the middle-aged individuals at its baseline.

\section{Conclusions}

The association of memory with adiponectin in middleaged individuals, preceding overt diabetes, suggests that this adipokine might anticipate the cognitive function impairment when preventive strategies could be more effectively implemented. Whether adiponectin circulating levels could be useful to identify those at a higher risk for cognitive dysfunction before advanced age need to be prospectively investigated. Deepening knowledge about novel therapies against Alzheimer's disease, based on the neuroprotective effect of adiponectin in amyloid B neurotoxicity, is also necessary.

\begin{abstract}
Authors' contributions
AC participated in the study design, organization of the data, analysis of biomarkers, statistical analysis, interpretation of the results, draft the article.

CKS participated in the review of the statistical analysis and of the article. IMB conceived of the ELSA-Brasil study, participated in interpretation of the results and review of the article. PAL conceived of the ELSA-Brasil study, participated in interpretation of the results and review of the article. BAP participated in the design of the study, interpretation of the results and review of the article. SRGF conceived of the actual study, participated in the interpretation of the results and manuscript correction, and reviewed the final version. All authors read and approved the final manuscript.
\end{abstract}

\section{Author details}

${ }^{1}$ Department of Epidemiology, School of Public Health, University of Sao Paulo, São Paulo, Brazil. ${ }^{2}$ Division of Geriatrics, Medical School, University 
of Sao Paulo, São Paulo, Brazil. ${ }^{3}$ Department of Internal Medicine, Medical School, University of Sao Paulo, São Paulo, Brazil.

\section{Acknowledgements}

The authors would like to acknowledge the participation of the 15,105 individuals recruited for this study without which this study and those based on the ELSA-Brasil cohort would not have been possible.

The ELSA Research Group Estela M. L. Aquino, Eduardo L. A. Mota (Instituto de Saúde Coletiva, Universidade Federal da Bahia, Salvador, Brazil); Sandhi Maria Barreto, Valéria Maria Azeredo Passos (Faculdade de Medicina, Universidade Federal de Minas Gerais, Belo Horizonte, Brazil); Dóra Chor, Marilia S. Carvalho (Escola Nacional de Saúde Pública, Fundação Oswaldo Cruz, Rio de Janeiro, Brazil); Isabela M. Bensenor, Paulo A. Lotufo (Faculdade de Medicina, Universidade de São Paulo, Sao Paulo, Brazil); José Geraldo Mill, Maria Del Carmen Molina (Universidade Federal do Espírito Santo, Espírito Santo, Brazil); Bruce B. Duncan, Maria Inês Schmidt (Faculdade de Medicina, Universidade Federal do Rio Grande do Sul, Porto Alegre, Brazil); and Moyses Szklo (Department of Epidemiology, Bloomberg School of Public Health, Johns Hopkins University, Baltimore, Maryland).

\section{Competing interests}

The authors declare that they have no competing interests.

\section{Availability of data and materials}

The datasets used and/or analyzed during the current study are available from the corresponding author on reasonable request.

\section{Funding}

The current work was supported by grant from the São Paulo Research Foundation (Fundação de Amparo à Pesquisa do Estado de São PauloFAPESP_Protocol 2009/15041-9), São Paulo, SP, Brazil and from the National Postdoctoral Program (PNPD-CAPES), Brazil. The ELSA-Brasil baseline study was supported by the Brazilian Ministry of Health (Science and Technology Department) and the Brazilian Ministry of Science and Technology and CNPqNational Research Council) (Grants \# 01060010.00 RS, 01060212.00 BA, 0106 0300.00 ES, 01060278.00 MG, 01060115.00 SP, 01060071.00 RJ).

\section{Publisher's Note}

Springer Nature remains neutral with regard to jurisdictional claims in published maps and institutional affiliations.

Received: 2 May 2018 Accepted: 28 June 2018

Published online: 09 July 2018

\section{References}

1. Spranger J, Kroke A, Möhlig M, Bergmann MM, Ristow M, Boeing H, Pfeiffer AF. Adiponectin and protection against type 2 diabetes mellitus. Lancet. 2003;361:226-8.

2. Aleidi S, Issa A, Bustanji H, Khalil M, Bustanji Y. Adiponectin serum levels correlate with insulin resistance in type 2 diabetic patients. Saudi Pharm J. 2015;23:250-6.

3. Tilg H, Moschen AR. Adipocytokines: mediators linking adipose tissue, inflammation and immunity. Nat Rev Immunol. 2006;6:772-83.

4. Song J, Lee JE. Adiponectin as a new paradigm for approaching Alzheimer's disease. Anat Cell Biol. 2013;46:229-34.

5. Qiu G, Wan R, Hu J, Mattson MP, Spangler E, Liu S, Yau SY, Lee TM, Gleichmann M, Ingram DK, et al. Adiponectin protects rat hippocampal neurons against excitotoxicity. Age (Dordr). 2011;33:155-65.

6. Kiliaan AJ, Arnoldussen IA, Gustafson DR. Adipokines: a link between obesity and dementia? Lancet Neurol. 2014;13:913-23.

7. Chen B, Liao WQ, Xu N, Xu H, Wen JY, Yu CA, Liu XY, Li CL, Zhao SM, Campbell W. Adiponectin protects against cerebral ischemia-reperfusion injury through anti-inflammatory action. Brain Res. 2009;1273:129-37.

8. Kalaria RN, Maestre GE, Arizaga R, Friedland RP, Galasko D, Hall K, Luchsinger JA, Ogunniyi A, Perry EK, Potocnik F, et al. Alzheimer's disease and vascular dementia in developing countries: prevalence, management, and risk factors. Lancet Neurol. 2008;7:812-26.
9. Imtiaz B, Tolppanen AM, Kivipelto M, Soininen H. Future directions in Alzheimer's disease from risk factors to prevention. Biochem Pharmacol. 2014:88:661-70.

10. Chatterjee S, Peters SA, Woodward M, Mejia Arango S, Batty GD, Beckett $\mathrm{N}$, Beiser A, Borenstein AR, Crane PK, Haan M, et al. Type 2 diabetes as a risk factor for dementia in women compared with men: a pooled analysis of 2.3 million people comprising more than 100,000 cases of dementia. Diabetes Care. 2016;39:300-7.

11. McCrimmon RJ, Ryan CM, Frier BM. Diabetes and cognitive dysfunction. Lancet. 2012;379:2291-9.

12. Ma L, Wang J, Li Y. Insulin resistance and cognitive dysfunction. Clin Chim Acta. 2015:444:18-23.

13. McNay EC, Ong CT, McCrimmon RJ, Cresswell J, Bogan JS, Sherwin RS. Hippocampal memory processes are modulated by insulin and high-fatinduced insulin resistance. Neurobiol Learn Mem. 2010;93:546-53.

14. Kim B, Feldman EL. Insulin resistance as a key link for the increased risk of cognitive impairment in the metabolic syndrome. Exp Mol Med. 2015;47:e149.

15. De Felice FG, Lourenco MV, Ferreira ST. How does brain insulin resistance develop in Alzheimer's disease? Alzheimers Dement. 2014;10:S26-32.

16. Roriz-Filho SJ, Sá-Roriz TM, Rosset I, Camozzato AL, Santos AC, Chaves ML, Moriguti JC, Roriz-Cruz M. (Pre)diabetes, brain aging, and cognition. Biochem Biophys Acta. 2009;1792:432-43.

17. Sperling R, Mormino E, Johnson K. The evolution of preclinical Alzheimer's disease: implications for prevention trials. Neuron. 2014;84:608-22.

18. Gregory MA, Boa Sorte Silva NC, Gill DP, McGowan CL, Liu-Ambrose T, Shoemaker JK, Hachinski V, Holmes J, Petrella RJ. Combined dual-task gait training and aerobic exercise to improve cognition, mobility, and vascular health in community-dwelling older adults at risk for future cognitive decline. J Alzheimers Dis. 2017;57:747-63.

19. Aquino EM, Barreto SM, Bensenor IM, Carvalho MS, Chor D, Duncan BB, Lotufo PA, Mill JG, Molina MEC, Mota EL, et al. Brazilian Longitudinal Study of Adult Health (ELSA-Brasil): objectives and design. Am J Epidemiol. 2012;175:315-24

20. Schmidt MI, Duncan BB, Mill JG, Lotufo PA, Chor D, Barreto SM, Aquino EM, Passos VM, Matos SM, Molina MEC, et al. Cohort profile: longitudinal Study of Adult Health (ELSA-Brasil). Int J Epidemiol. 2015;44:68-75.

21. Almeida-Pititto B, Ribeiro-Filho FF, Lotufo PA, Bensenor IM, Ferreira SR. Novel biomarkers of cardiometabolic risk are associated with plasma glucose within non-diabetic range. The Brazilian Longitudinal Study of Adult Health-ELSA-Brasil. Diabetes Res Clin Pract. 2015;109:110-6.

22. Welsh K, Butters N, Hughes J, Mohs R, Heyman A. Detection of abnormal memory decline in mild cases of Alzheimer's disease using CERAD neuropsychological measures. Arch Neurol. 1991;48:278-81.

23. Suemoto CK, Santos IS, Bittencourt MS, Pereira AC, Goulart AC, RundekT, Passos VM, Lotufo P, Benseñor IM. Subclinical carotid artery atherosclerosis and performance on cognitive tests in middle-aged adults: baseline results from the ELSA-Brasil. Atherosclerosis. 2015;243:510-5.

24. Passos VM, Giatti L, Barreto SM, Figueiredo RC, Caramelli P, Benseñor I, da Fonseca MEJ, Cade NV, Goulart AC, Nunes MA, et al. Verbal fluency tests reliability in a Brazilian multicentric study, ELSA-Brasil. Arq Neuropsiquiatr. 2011;69:814-6.

25. Lewis G, Pelosi AJ, Araya R, Dunn G. Measuring psychiatric disorder in the community: a standardized assessment for use by lay interviewers. Psychol Med. 1992;22:465-86.

26. Brunoni AR, Nunes MA, Figueiredo R, Barreto SM, da Fonseca MEJ, Lotufo PA, Benseñor IM. Patterns of benzodiazepine and antidepressant use among middle-aged adults. The Brazilian Longitudinal Study of Adult Health (ELSA-Brasil). J Affect Disord. 2013;151:71-7.

27. Matsudo S, Matsudo V, Rodrigues, Andrade DR, Araújo TL, Andrade E, Oliveira L, Braggion G. Physical activity promotion: experiences and evaluation of the Agita São Paulo program using the ecological mobile model. J Phys Activity Health. 2004;1:16.

28. Matsudo S, Araujo T, Matsudo V, Andrade D, Andrade E, Oliveira LC, Braggion G. Questionário internacional de atividade física (IPAQ): Estudo de validade e reprodutibilidade no Brasil. Rev Bras Atividade Física e Saúde. 2001;6(2):14.

29. Bensenor IM, Griep RH, Pinto KA, Faria CP, Felisbino-Mendes M, Caetano El, Albuquerque LAS, Schmidt MI. Routines of organization of clinical tests and interviews in the ELSA-Brasil investigation center. Rev Saude Publica. 2013:47(Suppl 2):37-47. 
30. American Diabetes Association. Diagnosis and classification of diabetes mellitus. Diabetes Care. 2014;37(Suppl 1):S81-90.

31. Fedeli LG, Vidigal PG, Leite CM, Castilhos CD, Pimentel RA, Maniero VC, Mill JG, Lotufo PA, Pereira AC, Bensenor IM. Logistics of collection and transportation of biological samples and the organization of the central laboratory in the ELSA-Brasil. Rev Saude Publica. 2013;47(Suppl 2):63-71.

32. Katzman R. Education and the prevalence of dementia and Alzheimer's disease. Neurology. 1993;43:13-20.

33. Farfel JM, Nitrini R, Suemoto CK, Grinberg LT, Ferretti RE, Leite RE, Tampellini E, Lima L, Farias DS, Neves RC, et al. Very low levels of education and cognitive reserve: a clinicopathologic study. Neurology. 2013;81:650-7.

34. Proust-Lima C, Amieva H, Letenneur L, Orgogozo JM, Jacqmin-Gadda $H$, Dartigues JF. Gender and education impact on brain aging: a general cognitive factor approach. Psychol Aging. 2008;23:608-20.

35. van Hooren SA, Valentijn AM, Bosma H, Ponds RW, van Boxtel MP, Jolles J. Cognitive functioning in healthy older adults aged 64-81: a cohort study into the effects of age, sex, and education. Neuropsychol Dev Cogn B Aging Neuropsychol Cogn. 2007:14:40-54.

36. Laws KR, Irvine K, Gale TM. Sex differences in cognitive impairment in Alzheimer's disease. World J Psychiatry. 2016:6:54-65.

37. Ashby-Mitchell K, Jagger C, Fouweather T, Anstey KJ. Life expectancy with and without cognitive impairment in seven Latin American and Caribbean countries. PLoS ONE. 2015;10:e0121867.

38. Sherwin BB. Estrogen and/or androgen replacement therapy and cognitive functioning in surgically menopausal women. Psychoneuroendocrinology. 1988;13:345-57.

39. Reitz C, Guzman VA, Narkhede A, DeCarli C, Brickman AM, Luchsinger JA. Relation of dysglycemia to structural brain changes in a Multiethnic Elderly Cohort. J Am Geriatr Soc. 2017;65:277-85.

40. Luchsinger JA, Tang MX, Shea S, Mayeux R. Hyperinsulinemia and risk of Alzheimer disease. Neurology. 2004:63:1187-92.

41. Mercuro G, Deidda M, Piras A, Dessalvi CC, Maffei S, Rosano GM. Gender determinants of cardiovascular risk factors and diseases. J Cardiovasc Med (Hagerstown). 2010;11:207-20.

42. Wilson RS, Boyle PA, Yu L, Barnes LL, Sytsma J, Buchman AS, Bennett DA, Schneider JA. Temporal course and pathologic basis of unawareness of memory loss in dementia. Neurology. 2015;85:984-91.

43. Awad N, Gagnon M, Messier C. The relationship between impaired glucose tolerance, type 2 diabetes, and cognitive function. J Clin Exp Neuropsychol. 2004;26:1044-80.

44. Biessels GJ, Deary IJ, Ryan CM. Cognition and diabetes: a lifespan perspective. Lancet Neurol. 2008:7:184-90.

45. Sanz CM, Ruidavets JB, Bongard V, Marquié JC, Hanaire H, Ferrières J, Andrieu S. Relationship between markers of insulin resistance, markers of adiposity, $\mathrm{HbA1C}$, and cognitive functions in a middle-aged populationbased sample: the MONA LISA study. Diabetes Care. 2013;36:1512-21.

46. Mito T, Miura S, Iwata A, Morii J, Sugihara M, Ike A, Mori K, Kawamura A, Nishikawa H, Zhang B, Saku K. Determination of the cut-off plasma adiponectin level associated with a lower risk of restenosis in patients with stable angina. Coron Artery Dis. 2011;22:451-7.

47. Bedse G, Domenico FD, Serviddio G, Cassano T. Aberrant insulin signaling in Alzheimer's disease: current knowledge. Front Neurosci. 2015;9:204

48. Cholerton B, Baker LD, Craft S. Insulin, cognition, and dementia. Eur J Pharmacol. 2013;719:170-9.

49. Gerstorf D, Herlitz A, Smith J. Stability of sex differences in cognition in advanced old age: the role of education and attrition. J Gerontol B Psychol Sci Soc Sci. 2006;61:P245-9.

50. Yamauchi T, Iwabu M, Okada-Iwabu M, Kadowaki T. Adiponectin receptors: a review of their structure, function and how they work. Best Pract Res Clin Endocrinol Metab. 2014;28:15-23.

51. Iwabu M, Okada-Iwabu M, Yamagushi T, Kadowaki T. Adiponectin/ adiponectin receptor in disease and aging. NPJ Aging Mech Dis. 2015;1:15013.

52. Nicolas S, Cazareth J, Zarif H, Guyon A, Heurteaux C, Chabry J, Petit-Paitel A. Globular adiponectin limits microglia pro-inflammatory phenotype through an AdipoR1/NF-kB signaling pathway. Front Cell Neurosci. 2017;11:352.

53. Arnoldussen IA, Kiliaan AJ, Gustafson DR. Obesity and dementia: adipokines interact with the brain. Eur Neuropsychopharmacol. 2014;24:1982-99.

54. Chan KH, Lam KSL, Cheng OY, Kwan JSC, Ho PWL, Cheng KKY, Chung SK, Ho JWM, Guo VY, Xu A. Adiponectin is protective against oxidative stress induced cytotoxicity in amyloid-beta neurotoxicity. PLoS ONE. 2012;7(12):e52354.

55. van Himbergen TM, Beiser AS, Ai M, Seshadri S, Otokozawa S, Au R, Thongtang N, Wolf PA, Schaefer EJ. Biomarkers for insulin resistance and inflammation and the risk for all-cause dementia and Alzheimer disease: results from the Framingham Heart Study. Arch Neurol. 2012;69:594-600.

56. Waragai M, Adame A, Trinh I, Sekiyama K, Takamatsu Y, Une K, Masliah E, Hashimoto M. Possible involvement of adiponectin, the anti-diabetes molecule, in the pathogenesis of Alzheimer's disease. J Alzheimers Dis. 2016:52:1453-9.

57. Waragai M, Ho G, Takamatsu Y, Shimizu Y, Sugino H, Sugama S, Takenouchi T, Masliah E, Hashimoto M. Dual-therapy strategy for modification of adiponectin-associated chronic diseases. Drug Discov Today. 2018 https://doi.org/10.1016/j.drudis.2018.05.009 (in press)
Ready to submit your research? Choose BMC and benefit from:

- fast, convenient online submission

- thorough peer review by experienced researchers in your field

- rapid publication on acceptance

- support for research data, including large and complex data types

- gold Open Access which fosters wider collaboration and increased citations

- maximum visibility for your research: over 100M website views per year

At BMC, research is always in progress.

Learn more biomedcentral.com/submissions 